\title{
Multicultural Societies: Kálmán Mikszáth, Pál Závada and Péter Huncik ${ }^{1}$ Enikő Molnár Basa, Library of Congress
}

\begin{abstract}
Three Hungarian works, one from the $19^{\text {th }}$ century and two contemporary novels, reflect changing attitudes to ethnicity and nationality questions within Hungary, including the area that became part of Czechoslovakia after World War I. Kálmán Mikszáth’s Tót Atyafiak shows a society in which the various nationalities of Upper Hungary live in harmony. Ethnic problems seem not to be present. Pál Závada’s Jadviga Párnája presents a more complex picture: while the protagonists seem free of nationalistic sentiments, they are conscious of their Slovak roots, their customs and language. A majority in the city and community which forms the backdrop to the story, they are a minority in the larger region of the Hungarian Plain. However, different customs and language are not perceived as setting themselves off from other Hungarians. Outside forces and prejudices do intrude since key sections of the story occur during World War I and its aftermath. The third novel, Péter Hunčik's Határeset examines the fate of the population of Ipolyság, a town in what is now southern Slovakia. This is an area which still has a large Hungarian population; many families nevertheless have a background that includes Slovak and other nationalities. With the border changes of 1920, 1938 and 1945 lives are disrupted. Communism further complicates the tensions and absurdities fueled by outside forces. The works are testimonies to tolerance because the protagonists most affected are open to other ethnicities, other nationalities.
\end{abstract}

Keywords: ethnic studies, multiculturalism, Hungarian minorities, Hungarians in Slovakia, Hungarian literature

Biography: Enikő Molnár Basa received her Ph.D. in comparative literature from the University of North Carolina at Chapel Hill. She taught at universities in the Washington, DC area before accepting a position at the Library of Congress. She is a founder and currently Executive Director of the American Hungarian Educators Association, as well as an active member of the Southern Comparative Literature Association and the Modern Language Association, where she has served on the Board of the Hungarian Discussion Group. Her publications include Sándor Petöf $f$ in the Twayne World Authors Series. She was editor of the series and saw four other works to publication. She edited Hungarian Literature in the Review of National Literature series. In addition to articles published in various journals, both in the United States and Hungary, she has presented papers on various aspects of Hungarian literature at scholarly conferences. In 2002-2003 she was Kluge Staff fellow at the Library of Congress and is currently working on a book that will be largely based on research begun at the time. It will examine the work of poets as "spokesmen for the nation" when political and social commentary was stifled.

Majority-minority relations, discrimination, intertwined histories and families, power plays, violations of rights, real and imagined abuses of authority infuses much of the hisstory of the Carpathian Basin. In examining the three Hungarian literary works I have chosen, I look at Slovak-Hungarian relations through the lenses of Kálmán Mikszáth’s Tóth Atyafiak (Slovak Relations), Pál Závada’s Jadviga Párnája, (Jadviga's Pillow) and Péter Hunčik's Határeset (Border Incident). While different in many ways, what is interesting is that each deals with questions of minority vs. majority, the relationship between ethnic groups, and the sense of identity which infuses, or fails to infuse, the characters.

The problems, of course, have not been solved by the fall of authoritarian regimes or the easing of borders through the European Union, just as they existed before the dissolution of the Hungarian Kingdom. In fact, the first two works take place largely within the context of a multi-cultural Hungary, while the third finds the Hungarians as the minority group in Czechoslovakia. The discriminatory language laws in Slovakia, not to mentions the refusal to retract the highly discriminatory Beneš decrees, ${ }^{2}$ attacks on Hungarian monuments, and maybe most blatantly the recent (March 22, 2011) call on the part of the Slovak politician Jan Slota to expel all Hungarians (and Roma) from Slovakia (Népujság) show that the problems 
Basa,Enikő Molnár. "Multicultural Societies: Kálmán Mikszáth, Pál Závada and Péter Huncik." AHEA: E-journal of the American Hungarian Educators Association, Volume 5 (2012): http://ahea.net/e-journal/volume-5-2012

have in some ways only intensified. Books that explore the relations between the ethnicities of the region can thus bring people to a better understanding of the complex threads that weave through the ethnic question.

Kálmán Mikszáth (1847-1910) was born in Sklabonya, Nógrád County and in his first successful works, Tót atyafiak (1881 Slovak Relations) and A jó palócok (1882 The Good Palóc), he wrote about the people of his home region of Hungary. Located in the north central area of historic Hungary, by the nineteenth century the region was at the linguistic and ethnic border between Hungarians and Slovaks. The area is now part of Slovakia, awarded to the Czechoslovak Republic following Word War I, but in Mikszáths's time it was an integral part of the Kingdom of Hungary. Mikszáth took the multiethnic nature of the area for granted and wrote about both the Hungarian and Slovak populations with empathy. A member of the gentry, he lived close to the people although also removed from them: he studied law, became a journalist, and later a Member of Parliament when already an acclaimed author. It was the collection of stories in the two works mentioned above which established his literary fame.

In politics Mikszáth was a nineteenth century liberal who believed that reforms such as the extension of the franchise and the abolition of all vestiges of feudalism would solve the nationalities problem.

(Feudalism and all feudal obligations had been abolished in 1848, but some customs remained which curtailed the opportunities of the peasants, regardless of their ethnicity). As an author, he idealized the nép (variously translatable as "folk," "peasant," "populace”) and in this made no difference among the ethnic groups of his home region. Kálmán Mikszath took the coexistence of Hungarians, Slovaks, and Germans as part of the natural order in Upper Hungary. As Antal Szerb notes, "[t]he peasants of Tót atyafiak form one of the high points of Hungarian népiesség (popularism) because here the "folk" is folk only inasmuch as they are simple people free of the falseness of higher culture; [they are] essentially human, essentially soul" ${ }^{3}[A$ jó palócok és a Tót atyafiak parasztjai azért jelentik a magyar irodalmi népiesség egyik tetöfokát, mert itt a nép csak annyiban nép, hogy tisztán emberi, mentes a magasabb kultúra álságaitól, maga az ember, maga a lélek] (439). In A Magyar irodalom története (The History of Hungarian Literature) Kálmán Kovács writes that there is something of the resignation of the Compromise of 1867 in Mikszáth's Slovak peasants, who seem to lack a rebellious spirit (711). I believe this is a misinterpretation: Mikszáth shows his Slovak peasants as passionate as the Hungarians in what touches them personally. Such passion is shown most in the story entitloed “Az a fekete folt” (That Black Spot).

Mikszáth draws on memories of his childhood and youth when the village was still ruled in a patriarchal way and traditions were strong. Justice is as often served by fate and necessity as by the law, and the retributive atmosphere of the ballad informs many of his works, as Kovács points out (711). Such generalizations that I am making here should not be carried to an extreme, however, for Mikszáth was also aware of contemporary realities. In writing about the Slovaks in Tóth Atyafiak he displays the same gentle irony as he does towards the Hungarian Palóc. Whatever condescension or humor there is, it is directed at their simplicity; but for this simplicity there is also considerable admiration. Social status and position rather than ethnicity determine a person's standing in the community. Often the simplest persons are shown to be the noblest. The simple shepherd in "Az a fekete folt" is nobler than the princely landlord, who is a certified cad. Social class, not ethnicity (we do not even know the ethnicity of the Hungarian-Austrian landlord) drives the tragedy. The rage and shame of Tamás Olej reaches tragic proportions when he realizes that his landlord, Prince Pál, the owner of the estate of Talár, falls for Anika, Olej's daughter. She is not averse to his advances, but is presented as a simple girl seduced by the blandishments of a handsome young man. When Olej confronts the prince to order him to leave his daughter alone, the prince offers a bribe: the sheep pen, pasture and the thousand head of sheep which were in Olej's care. Although Olej rejects the offer, the prince states that he will take the girl to Vienna nevertheless, with or without Olej's permission. Plagued by his conscience for even considering the offer, Olej returns to his home from the grazing grounds the following day to find Anika gone and the bill of sale left in her stead. In rage and shame he sets fire to the sheep pen with all of the sheep locked inside and wanders off to the mountains never to be heard from again. A folk song memorializes the event: 
There, out on the Brezina that black spot,

At its site once there was a sheep pen...

Ott künn a Brezinán az a fekete folt,

Fekete folt helyén valaha akol volt... (90)

Similarly, Lapaj, the bagpiper in "Lapaj, a híres dudás”, becomes a noble character when touched by the need of an infant. In "Jasztrábék pusztulása" the notorious outlaw is brought to justice by the Hungarian authorities, but he had preyed on all of the inhabitants. The chief police officer, István Gerge, simply uses his clever methods based on knowledge of human nature and local superstition to elicit a confession from him. There is no hint of a majority abusing its powers toward the minority since part of the credentials of Gerge are that he uncovered a theft of Hungarian cattle to the Habsburg treasury some time earlier. We are not told the methods, but undoubtedly it was using the same insight into human nature. A nice touch is in the ending of the tale: Jasztrab, having confessed to various crimes, is charged with the murder of his grandfather, and responds: "Whose busineness is that?... After all, he was my own grandfather," and the policeman simply responds: "That is true, my son... you are truly right. But, you know, the county takes this in a very crazy way” [Kinek mi köze hozza? ... Hiszen az én tulajdn öregapám volt! Igaz, fiam ... [sic] tökéletesen igazad van! Csakhogy tudod, a vármegye szörnyen bolundul veszi a dolgot] (142).

Little attention has been paid to ethnic issues in Mikszáth criticism in Hungary, but an article by Karol Wlachovskký, looking at the work from a Slovak perspective, confirms my assessment that the Hungarian author was as sympathetic to his Slovak subjects as to his Hungarian ones. The writer points out, first of all, that in the nineteenth century "Tót” as a designation for Slovak, carried no pejorative connotations (1). He also recognizes that Mikszáth rejected efforts by the Hungarian government at "Hungarianization” of the Slovak population. Wlachovskký quite correctly points out that for Mikszáth Upper Hungary was inhabited by Slovaks as well as Hungarians and Germans, and this was seen as a given. I would not agree with him, however, that "the most important characteristic of Mikszáth's Uplands is the presence of the Slovak people” [Mikszath Felföldjének legfontosabb jellemzöje a szlovák nép jelenléte] (2). More correctly, it was a multi-ethnic landscape that Mikszáth surveyed, and the Slovak presence was only one factor.

A good example of ethnic coexistence in Upper Hungary is seen in one of the most charming of the tales, "Az Aranykisasszony” (The Golden Miss). The tale depicts life in the multi cultural city of Selmec (Selmecbánya or Banská Śtiavnica), where Germans and Hungarians mingle with the Slovak population; all of the characters are fallible. Krisztina Csemez, whose father is the chemistry professor at the local gyimnazium, is probably Hungarian, but her best friend is Bohuska Mirkovszki and her fiancé turns out to be Bohuska's brother. They are, judging from their names, both Slovak, and the mining engineer, Demeter Luppán might be German, but that is not the point: they are all part of the tight circle of Csemez's friends. So is István Csutkás, also a professor at the school, whose claim to fame is having taught Petöfi when the poet spent a few semesters in Selmec. Ironically, it was here that the poet got into trouble for his Hungarian sentiments and had a run-in with a Pan-Slav teacher - facts that are conveniently forgotten by this little selfcentered group. There is an easy mixing of ethnicities, and whatever conflicts there are, are not ethnic ones. Thus, Miklós Mirkovszki, who has just completed his university studies and is slated to become one of the engineers in the mining town, is accepted as an appropriate suitor for Krisztina. This is how he is described:

Miklós Mirkovszki ... arrived home merely a half year earlier, so that he could augment his local [meaning, I believe, Hungarian, i.e. in Budapest] legal studies at the Mining Academy, and if lucky, he could set out on life with the hope that at one time he could even be a member of the mining board.

Mirkovszki Miklós ... mindössze fél ev óta került haza, hogy itthoni jogi tanulmányait kiegészitse a bánya akademian, s ha jó szerencse kedvez, nekiindulhasson az életnek azon reménnyel, hogy valaha még bányatanácsos is lehet belöle. (30-31) 
Basa,Enikő Molnár. "Multicultural Societies: Kálmán Mikszáth, Pál Závada and Péter Huncik." AHEA: E-journal of the American Hungarian Educators Association, Volume 5 (2012): http://ahea.net/e-journal/volume-5-2012

Mr. Csemez greets Mirkovszki’s asking for his daughter’s hand thus: "Now, my son, that is very good....I know your father. He is an upright, honorable man and my good friend” ('Nos öcsém, nagyon jól van... Ösmerem az apádat. Derék, becsületes ember és jó barátom’ (41)). It is only Mr. Csemez’s unreasonable request that Krinsztina's husband deliver her weight in gold which puts the marriage on hold. Miklós sets out for the gold fields of California; years pass, and he is reputed by some to have struck it rich there. Or, maybe he just vanished as so many others did who emigrated. In any case, he fails to return, and even though Krisztina loses weight to simplify his task and in time even her father forgets about his condition, she lives out her life as an old maid, faithful to her betrothed. The language, but also in the way both Slovak and Hungarian names are easily incorporated in discourse, shows an easy intercourse among the various groups: so, for example, István Csutkás, the professor, becomes Stevo without loss of identity. This is in contrast to the soul-searching which accompanies the characters in Határeset when forced to choose between the Hungarian and the Slovak forms of their Christian names to avoid expulsion from their hometown. As a sort of coda to the use of names in this story by Mikszáth, I would like to return to Wlachovský's assessment. Mikszáth, he contends, was led more by sound symbolism than ethnic considerations in his choice of names, and also by a desire to enhance the realism of the tales in choosing names typical of the region and reflective of both ethnicity and religion (3).

Bilingualism of the main characters also stamps Pál Závada’s novel Jadviga Párnája (Jadviga’s Pillow), which takes place in a Slovak town in Békés County, an island of Slovak settlement within a largely Hungarian population. Set primarily in the early decades of the twentieth century, some events reach back to a generation earlier, while the final diary entry is in 1987. The town and region was settled in the eighteenth century by Slovaks from Upper Hungary who had become largely assimilated while keeping their customs and to some extent their language. Závada (1954-) modeled this town on his hometown of Tótkomlós, where even in his childhood a mixture of the two languages was still spoken. For everyday communication, particularly household and farming vocabulary, Slovak was adequate, although it was an archaic Slovak. Public and more sophisticated discourse, and of course the written word, tended to be Hungarian. The novel is in the form of a diary written by András Osztatní from 1915 through 1922 or 23; his wife, Mária Jadviga Palkovits takes it up after his death in 1937 and continues it up to the end of the Second World War. After her death in 1954, her son writes his commentary and explanatory notes on he original diaries. Thus we have an intimate glimpse into the lives of this family and of the community. In terms of language, both András/Ondris and Jadviga use Slovak terms of endearment and freely mix the two languages. Others in the community also use both languages in a more or less natural manner, often mixing the two in much the same way as Hungarians in the United States will also add Hungarian endings to English words and English words find their way into what has come to be known as Hunglish. Only in the insertions and comments by Jadviga's son is it clear that while he also still knows Slovak, this is no longer the shared language of the community for he translates or explains the Slovak terms.

In his novel Závada, a sociologist by training, is more interested in interpersonal relations, and particularly the tortured relationship of Ondris and Jadviga, than ethnic issues. Given the setting and the historical time frame, however, the latter cannot be ignored. According to Károly Alexa, the work can be placed within the tradition of regionalism, thus linking it to Mikszáth, who not incidentally is Ondris’ favorite author. This regionalism, however, did often draw on the "unique colors" of the varied regions of Hungary (107). Thus, questions of ethnicity surface in Závada’s novel indirectly even though, as in Mikszáth, the focus is not on ethnic problems. András is a wealthy farmer and a successful, if reluctant, leader of the community. He had attended gymnasium and is well-educated for his class, that is, he is from an upwardly mobile family. Jadviga had been educated abroad, the ward of Ondris' father, and does not really fit into the rural atmosphere. She has accepted Ondris proposal of marriage for reasons that are not entirely clear. It is suggested that this was the only option to her as an orphan with no good connections. Her affair with Franci Weisz, and frequent trips to Budapest, provide relief but obviously further estrange her from her husband. Ethnicity becomes an issue in the novel because Ondris wishes to keep on the right side of the local police but also remain close to his friends and church as World War I polarizes the region.

Although the hero of the novel, András/Ondris is not a Slovak nationalist, being only interested in his wife Jadviga and in the running of his estate, the irony is that it is through the couple's personal problems 
Basa,Enikő Molnár. "Multicultural Societies: Kálmán Mikszáth, Pál Závada and Péter Huncik." AHEA: E-journal of the American Hungarian Educators Association, Volume 5 (2012): http://ahea.net/e-journal/volume-5-2012

that the family declines, with the upheavals of the century providing more background than cause of this decline. Outside pressures force Ondris to take sides on political issues which he see as chiefly manufactured. For example, in the scene where, at his wife's urging, he attends a meeting at the house of the Pan Slavicist priest, Rev. Bacovszky, he notes that he had been largely unaware of the events of the world and is surprised by the nationalistic outburst of the priest:

We have to unite in the interests of our Slovakness! ... In this island of our nationality! Which is surrounded by those for whom 'porridge is not food, the Slovak is not a man!' And they bark at us with hate, to styekaju, zse 'buta tót’! (This was cited by Bacovszky in Hungarian eliciting the approving hums of Uncle Vajasdi.)

Össze kell tehát fognunk szlovákságunk védelmében!... Nemzetiségünk e szigetén! Melyet köröskörül vesznek azok, akiknek 'a kása nem étel, a tót nem ember!' S csak úgy csaholnak ránk gyülölettel, to styekaju, zse “buta tót!' Ezt Bacovzsky is magyarul idézte, kiváltva Vajasi bácsi elimerö hümmigését).

It is clear from comments about the food and drink that soon arrives that the participants don't take the meeting seriously and smile at the ardor of the priest. It is with some relief that Ondris can escape the meeting: "Fortunately doctor Hroncsok rises to take his leave, he still has to see patients, and I use this to also take my leave, so I am home for the making of the bed.” [Szerencsére Hroncsok doktor búcsúzásra emelkedik, hogy neki még betegekez kell menni, s ezt kihasználva én is elköszönök, így ágyazásra már haza is érek] (94).

World War I intrudes into the lives of Andris and Jadviga when Andris is drafted into the army on August 6, 1915. He sent to the front in Galicia but is released from service within a few months. When the draft notice first came, Andris, hoping to escape military service, had sought out Captain Szilágyi, a onetime friend of his father and commandant of the country's gendarmerie. This proves to be a fateful mistake: upon Andris release from the military, Szilágyi uses his supposed intercession to force Andris to spy on his neighbors. Szilágyi is interested in nationalistic feelings among the population and attributes more importance to these than is warranted. Similarly, the priest Bacovszky is a rabid nationalist who does not understand that his congregation is not interested in the political agenda he preaches. Ondris is reluctant to spy on his friends and does not see the whole question of ethnicity as an issue. His military experience, while brief, included some action, delineated in his "front novel." This short story is inserted in the diary after András returns from the front and relates the heroic actions of a Slovak (Tót) youth. But it is the comment on the soldiers' state of mind that is most telling:

Hungarian, Slovak, Jew and Austrian, Swabian, Croatian, Gypsy and Bosnian obeys German commands but calls on God, or curses Him, in his own language, as a man with a feeling heart, and inspired by Hungarian-style bravado, he fights his battles in this region.

Magyar, tót, zsido és osztrák, sváb, horvát, cigány és bosnyák, német vezényszóra engedelmeskedvén ugyan, ám a maga nyelvén hívja Istent vagy káromolva Öt, egy emberként, egy érzö szívvel s a magyar-módi virtussal átfütve vívja e tájon a harcát. (129)

Some critics have dismissed the ethnic content as merely one of setting. But we must not forget that the protagonists are Slovak and that they are influenced by historical events. The author recognized as much in an interview in which he noted that he sought to recreate the feel of his village (Beszelgetes). The events of the twentieth century also cannot be discounted. This is why Capt. Szilágyi continues to force Ondris to report to him on the activities and conversations of Ondris' neighbors. The distrust of Szilágyi and the agitation of Rev. Bacovszky for the community to reject Hungary and create its own autonomous region 
exacerbates ethic tensions. While the Rev. Bacovszky’s agitation can be dismissed by Ondris to a great extent, the attempts of Capt. Szilágyi to enlist him as a mole cannot be equally ignored. Szilágyi forces Ondris to list the names of his friends, and though Ondris does not give any relevant information (201) he us still bothered by the role of a spy. Soon the task, earlier only suggested, becomes quite explicit:

$[\mathrm{H}] \mathrm{e}$ only told me that I should go the next evening to Reverend Bacovszky, and that he wants to see me in the matter on Friday. ... I knew, of course, what sort of meeting is meant, because I had lied that they did not invite me. The "Slovak Evening," was similar to the earlier ones, and in the following months there were two more, so I do not even remember what happened when. But the next day I always had to relate to Szilágyi what had transpired in detail. If it interests him, it interests him. I shrugged my shoulders because the whole thing did not interest me in the least. I was fed up with Bacovszky's bombastic, snake-like circuitous phraseology about the flaming love in our breasts for our matyica homeland, our people, our land and our language and the unbreakable bonds of our loyalty.

\section{[A]nnyit hagyott csak meg, hogy másnap este menjek el Bacovszky} Tisztelendöhöz, pénteken pedig ez ügyben látni akar... Tudtam persze, hogy miféle összegyülésröl van szó, mert hazudtam én azt, hogy nem hívtak. A "slovákok estéje" külömben hasonló volt az elözöékhez, az utánna való hónapokban pedig követte még kettö, így már nem is emlékszem melyiken mi volt. De másnap mindig el kellett mondanom Szilágyinak, apróra. Ha érdekli, érdekli, vontam vállat, mert engem bizony nemigen izgatott az egész. Könyökömön jöttek már ki Bacsovszky dagályos, kígyótekergésü frázismondatai a matyica-hazánk, népünk, földünk és nyelvünk iránt kebelünkben lobogó szeretettröl s a hüség eltéphetetlen kötelékeiröl." (203)

Later, when told to attend a meeting by Szilágyhi which discusses Slovak autonomy, Ondris comments:

Furthermore, how can we be a district capital with official Slovak language usage. This seems to be the newest idea of the autonomy plan. But I don't know who will officially teach us to speak Slovak.

Továbba hogy legyünk mi járási székhley szlovák hivatalos nylevhasználattal.

Úgy látszik ez most az autonomia-terv legújabb ötlete. Csak azt nem tudom, ki fog miknket hivatalosan szlovákul megtanítanni. (231-232)

Ideas of national autonomy had surfaced earlier in the discourse of Bacovszkky. On October 17, 1917 András had noted that the priest spoke highly of Maszaryk, Benes, and others who were fighting for Slovak and Czech statehood (204). The idea of their own region in Békés being joined to far-away Slovak regions in Upper Hungary seems perposterous to András. (205) The diary entries for the early months of 1919 chronicle the turbulent period following the Armistice. All kinds of proposals for autonomous regions seem to be flying about so that it seems each region will want to be a separate entity, fragmenting the old order. András listens to his friends discuss the possibility of a Slovak state, but Miki, one of the group, points out that this is not likely: "The great Slovak national consciousness has been subsumed into that of the Czechs by Masaryk and his group and they have swallowed the Slovaks whole” [A nagy szlovák nemzettudatot Maszarykék beolvasztották a csehekébe, és szöróstül-böröstül bekapták a szlovákokat] (229)! As to their own region, another one of the group, Pali, comments that there is an idea floating around: according to the Reverend Backovszky, if push comes to shove, Slovakian autonomy could be envisaged under Romamian rule. The idea is rejected vehemently by most of the group: 
Are you mad brother! Slovak autonomy under a Romanian state?! Isn't Hungary good for you? Isn't it enough trouble for you that you wish to whip your own tail, but in addition you would move out of the room into the bison stall?

Meg vagy kergülve, testvér! Szlovák autonómia román államiság alatt? Nem jó nektek Magyarország? Hát nem elég neked bajnak, hogy örökre magad akarod a saját farkadat kiverni, de ehhez még a szobából is kihurculkodnál a birkahodályba. (229)

While most condemn the ethnic slur, there seems to be general agreement among the citizens of the town that any kind of union with, or subservience to, Romania is an insult.

In the early months of the Károlyi government András is skeptical of the efforts toward both nationality and social issues. While he does not oppose measures to gain both nationality rights and to implement social reforms, he comments wryly:

With Bacovszky's leadership a deputation presented itself to the Government in Pest (!) the day before yesterday, with the petition of the local Slovaks, according to which, as I hear, the government should give us nationality rights, land to the landless from the neighboring landowners, build houses for the homeless, and also a narrow gauge railway. I believe this brave government cannot think of anything more timely than such plans.

Bacovszky vezetésével tegnapnelött deputáciú járt Pesen a kormánynál (!) a helyi szlovakság folyamodványával, miszerint, mint hallom, ajdon a kormány nekünk nemzetiségi jogot, a földteleneknek földet a szomszéd uradalmakéból, építsen a háztalanaknak házat meg még keskeny nyomtávú vasutat is. Szerintem ez a dekék kormány mit sem tart most idöszerübb gondjának az ilyesminél. (231)

As the Hungarian army falls apart and the Károlyi government is unable to defend the territory of Hungary, András notes that, in the wake of the sweep of French occupation troops, Romanian forces have descended on the town and are looting and pillaging:

It is rumored that the Romanians are allowed three days of looting. The people are loading wagons in a frenzy and driving the animals wherever they can. But the Romanian also sees what goes on, and so he stands on the roadsides, like the highwayman, drives away the owner, and all is his.

Azt rebesgetik, hogy háromnapi szabad rablás van a románoknak engedve. A nép tébolyultan pakol kocsikra, hajtja az állatát, ki merre tudja. De a román is látja, mi megy, ezért csak kiáll az utakra, mint betyárok, elkergeti a gazdat, és minden az övé. (237)

Andris' son, who will many years later also write in the diary, notes on the looting by Soviet soldiers in 1944: "It was the same with the Russians in '44. That too, was a robbing, hungry, tired, rabble. They went from farm to farm, looting” [Uganígy volt as oroszokkal 44-ben. Az is rabló, éhes, fáradt csürhe volt. Mentek tanyárol tanyára zabrálni] (237).

Linguistic/ethnic issues inform the work altough they are not the main theme. Závada has András express a tolerance also found in Mikszáth. Like his literary hero, András sees no difficulties in the coexistence of various ethnic groups, accepting Hungarian, Slovak, German, and even Jewish citizens as equal. Závada, however, depicts a society in which ethnic questions play a role even in spite of the major 
Basa,Enikő Molnár. "Multicultural Societies: Kálmán Mikszáth, Pál Závada and Péter Huncik." AHEA: E-journal of the American Hungarian Educators Association, Volume 5 (2012): http://ahea.net/e-journal/volume-5-2012

characters in his novel. Comments, digressions, the tone of the diary, all have to be taken seriousluy. For example, scattered Slovak phrases in the conversation of Jadviga and her husband need to be translated by their son since by the 1950's Hungarian had emerged as the major language of even the Slovak communities of Békés. The characters see themselves as largely passive players on the canvas of history. On August 14, 1919 András notes, almost by-the-way: "I hear that yesterday the leaders of our local Slovaks (among them, our Reverend Márton Bacovszky, revered for his wisdom as well) declared our annexation to Romania in the context of a popular meeting, in front of the County Court House" [Hallom, hogy tegnap honi szloválkjaink vezetői (köztük a mi bölcsességért is Tisztelendö Bacovszky Mártonunk) a megyeháza elött népgyülésen kiáltották ki csatlakoz-ásunkat Romániához] (271). Of course, nothing comes of the reverend Bacovszky's declation, but the lives of the people in the town are disrupted. When later the Horthy government is installed, Capt. Szilágyi is reinstated as chief of the police force and Andris is again asked to testify against his friends, some of whom are now accused of treason (271-277; 285; 290-294). Any sentiment related to Slovak nationalism or socialist ideology has become suspect.

So what to make of Jadviga's Parnája in ethnic terms? Ethnic issues are not the chief theme, yet neither can they be wholly ignored. Károly Alexa points out that, in spite of exceptions, minority issues have not drawn interest from Hungarian authors in the past, nor have they been a topic in recent literature. That is why Jadviga párnája is particularly interesting: it addresses Slovak nationality politics in the years of World War I and does this with a mixture of understanding and irony (106-107).

Both Alexa $(107,109)$ and the reviewer Ilona Legeza (1) comment on the work as being both a historical and a sociological novel, an interpretation with which I am not sure I would agree. The author himself has noted that maybe the work should be called a "romance" since it calls on the reader to engage his imagination. It is narrated by the characters themselves and overwritten by another person who corrects and comments, and so on, with an omniscient author being wholly absent (Rakovszky 8). So whatever social, ethnic, nationalistic or other views are presented, these are presented in a subjective way. Of course, this does not take away from the validity of the depiction of problems of the early twentieth century. It is fashionable nowadays to speak of "the Other" and set up a (sometimes) artificial barrier between peoples related by a common history and culture. I believe that in Jadvia Párnája Závada shows that a shared background is a stronger bond than artificially inflated “connections”of language, ethnicity, or whatever are the fashionable keywords of the day. Bacovszkky's pro-Slovak sentiments lead him to become so antiHungarian that he contemplates union with Romania: a state and people wholly alien to the Slovaks. With Hungary, at least, they have a shared history, and certainly most of the inhabitants of Békés speak some Hungarian and are comfortable within the multiethnic community.

Maybe, too, there is something in the assessment of Gergely Angyalosi as to why the novel has gained such popularity. He notes that there is a historical interest in our days "which focuses chiefly on the [twentieth] century and within that the events which sealed the fate of Hungarians; it is spiced up by certain ethnic and regional exoticism” [amely leginkább a század s benne a magyarság sorsát eldöntö eseményekre irányul: füszerezi mindezt némi etnikai-tájjellegi egzotikummal] (80).

The ethnic/nationalistic card continues to surface in Jadviga Párnája, whether as setting, language use, commentary, or the more realistic depiction of an ethnic community within the Hungarian nation. In a discussion by four literary critics, Gergely Angyalosi comments:

I did not miss either politics, or Slovak organizations, or the whole historical games along with the somewhat commonplace lessons which can be derived from these events. Hence, that the world of the monarchy appears as a realm of almost idyllic freedom. Then came the first repression, the Red Terror, then the Terror following 1919, etc., etc., and after that the even more horrible world of the fifties. This suggests commonplace lessons with the whole line of deterioration.

Nekem nem hiányzott sem a politika, sem a szlovák szerveszkedés, sem az egész történelmi játék, azokkal a kicsit közhelyes tanulságokkal, amelyek ebböl levonhatók. Tehát hogy a monarchia világa majdnem 
Basa,Enikő Molnár. "Multicultural Societies: Kálmán Mikszáth, Pál Závada and Péter Huncik." AHEA: E-journal of the American Hungarian Educators Association, Volume 5 (2012): http://ahea.net/e-journal/volume-5-2012

idillikus szabadság birodalmaként jelenik meg. Aztán jón az első elnyomás, a vörös terror, stb. stb., és utánna a még szörnyörübb ötvenes évek világa. Ez közhelyes tanulságot sugall az egész pusztullásvonallal együtt. (5)

The third work I will discuss in my examination of multiculrural societies is Péter Hunčik's Határeset (Border Incident), the author's first novel. Unlike the two previous works, this novel is written from the perspective of a minority population of Hungarians living in Slovakia, or more properly Czechoslovakia, and also examines the history of the $20^{\text {th }}$ century in this context. Péter Hunčik (1951-) is a psychiatrist, living and working in Dunajska Streda (Dunaszerdahely), southern Slovakia, where there is still a considerable Hungarian minority. So, he comes to the question from an angle different from the previous two authors. His early literary interests were stifled by censorship in the former Czechoslovakia, as Zsuzsanna Sandor points out in her summary of the author's life (3). After the fall of Communism he became active in politics and published primarily political and journalistic pieces. He served as an advisor to Vaclav Havel before the breakup of the Czechoslovak state. In 2009 he won the Sánsor Bródy prize for the best first novel of the year in Slovakia with Határeset. This portrayal of life in Ipolyág (Śahy) in this century examines ethnic relations in the multi-ethnic community in which the author grew up. Majority and minority changes with the sweep of history and Hunčik is sensitive to these changes.

Határeset documents the life of a town on the Hungarian/Slovak border and of its inhabitants in the turbulent years of the $20^{\text {th }}$ century. The region became part of the new Czechoslovak state after World War I. In 1938 it was returned to Hungary and the change of borders again confronts the inhabitants with fundamental questions. While the change seems civil (94) Feri notes that in his own family different languages are spoken and his grandmother has many Slovak friends. (88). At the same time, his father is adamant that the children be aware of their French heritage as well as their Hungarian roots (100; 139), even once the area again becomes part of Czechoslovakia. Pali, one of the principal narrators, ponders the nationality question as this is present in his own family: "Father was sixteen and he often thought about how could it be that his father is Slovak, his mother is Hungarian, and one of this grandfathers is half French" [Apu tizenhat éves volt, és sokszor gondolkoztott azon, hogy is van az, hogy az apja szlovák, az anya magyar, az egyik nagyapja meg félig francia] (268). Through the eyes of the child it becomes clear that the multiethnic mind frame of an earlier age no longer applies; in the post World War I world, one has to declare an ethnic allegiance no matter how difficult such a declaration might be.

In 1933 Pali's father, Géza Nemčak, had been taken on a visit to Alsókubin to visit the Slovak relatives there. He is surprised how much they are like the people of his own village, except for speaking another language. A few years later, when the Ipolyság and much of southern Slovakia is once more part of Hungry, Géza again has to confront the issue of language:

When they arrived home from the scouting trip, Dad asked Grandpa Nemčak if he also was a colonist in the city, like the Slovaks of Csallóköz. Grandpa laughed and said that he lives in this city because he feels good here. I am at home beside you, he said, and hugged Grandma.

And then Dad felt that maybe life is not witchcraft after all. Since he also felt at home here, beside his mother and his father, here in this city where Toncsi is also at home, and even the French Kányó grandfather can not be called a johnny come lately because his dead ones are resting in the cemetery also, all the way up his great grand dat, who was still called Cagneu.

Amikor hazaérkeztek a cserkészkiránulásról, apu megkrdezte Nemčak nagyapát, hogy vagyon ő is ilyen kolonista-e a városban, mint a csallóközi szlovákok. Nagypapa nevetett, és azt mondta, ö azért él ebben a városban, mert itt jól érzi magát. Én itt melletetek vagyon itthon, mondta, és megöletle nagymamát. És akkor apu úgy érezte, hogy talán mégsem boszorkányság az élet. Merthogy ö is itt, anyukája és apukája melett van itthon, ebben a 
Basa,Enikő Molnár. "Multicultural Societies: Kálmán Mikszáth, Pál Závada and Péter Huncik." AHEA: E-journal of the American Hungarian Educators Association, Volume 5 (2012): http://ahea.net/e-journal/volume-5-2012

városban Toncsi is itthon van, söt még a francia Kanyó nagyapának sem mondhatja senki, hogy gyüttment, mert a temetöben ott nyugszanak az ö halottai is, egészebn a dédnagyapjáig, akit még úgy hívták, hogy Cagneau. (269)

Following World War II the situation changes again. On returning home from a Prisoner of War camp in 1946, Géza Nemčak is surprised to learn that he is not welcome in his home town:

But when Dad came home from prison in forty-six, he reiterated in vain at the county courthouse that he is at home in this town. They sent him to the police station where wholly foreign persons sat at the desks. And in the whole building not a single person spoke Hungarian. But one could not hear Hungarian anywhere in the city. As soon as he arrived Aunt Bözsi met him with the news that is it forbidden to speak Hungarian in the whole country. And on the city square and in all of the streets a profound silence reigned because in the whole city there were hardly any who knew Slovak. And those who did know preferred to be silent and even at home only whispered to each other.

De amikor apu nagyvenhatban hazzajött a fogságból, hiába mondta a megyeházán, hogy ö itt, a városban van itthon. Elküldték öt a rendörségre, ahol csupa ismeretlen ember ült az asztaloknál. És az egész épületben egyetlen ember sem beszélt magyarul. De még a városban sem lehetett magyar szót hallani. Ahogy megérkezett, Bözsi néni rögtön azzal fogadta, hogy az egész országban tilos magyarul beszélni. És a fötéren meg az összes utcában nagy csend honolt, mert a városban alig akadt néhány ember, aki tudott volna szlovákúl. Akik meg tudtak, inkább hallgattak és otthon is csak halkan beszélgettek egymással. (269)

In order to avoid having to choose between his Hungarian and his Slovak roots, Géza decides to declare his nationality as French. He is confident that in this way he cannot be deported "since a Frenchman can hardly be deported from the center of Europe, and the deportation of two Frenchmen [a younger member of the family, Toncsi having decided to declare himself French as well] would constitute ethnic cleansing [Egy franciát mégsem lehet kitelepíteni Európa közepéböl, két francia kitelepitése neg már etnikai tisztogatának számított volna] (302).

Határeset is narrated chiefly by the cousins of the Kanyo/Cagneau and Nemčak families. Géza Nemčak, whose great grandfather on the mother's side was the Frenchman Cagneau, and whose paternal grandfather comes from the northern part of Upper Hungary. This is the grandfather who, in spite of his Slovak background, feels at home in Ipolyság. Géza bácsi (Uncle Géza) and Feri bácsi (Uncle Feri), are cousins and the parents of Pali and Tomi and Feri and István respectively. Between them, the four boys narrate twelve of the sixteen chapters of the work. They try to make sense of the politicks which confront them at every turn as they watch the struggles of the parents, are affected by political decisions in school, and hear family stories which cast a different light on history from that which is officially taught them in school. An example of the confusion a young child faces is given in the incident when Tomi, just starting kindergarten in 1956, plunges the family into danger. All the Hungarian schools were closed in 1945, but since almost none of the children in Ipolyság speak Slovak, Hungarian classes have to be started in the Czech schools. Tomi develops a crush on the Slovak kindergarten teacher, Anyicsaka, and wishes to be in her class, not the Hungarian. So, he seeks to draw her attention to himself, and gives a day-by-day account of the Revolution in class. Not only is it clear that the family listens to the banned Radio Free Europe, but also that the family discusses possibilities should Hungary leave the Soviet block. Radio Free Europe falsely promises help from the United States and Tomi wholly believes this. While there are no repercussions beyond detentions of some family members, Tomi's mother is advised to keep him home from school for a while. His father also metes out fairly serious punishment. What seems to have panicked the Czechoslovak 
Basa,Enikő Molnár. "Multicultural Societies: Kálmán Mikszáth, Pál Závada and Péter Huncik." AHEA: E-journal of the American Hungarian Educators Association, Volume 5 (2012): http://ahea.net/e-journal/volume-5-2012

administration was that they were afraid of a Hungarian takeover-more so than the threat to Communism:

... it became quite a little scandal, for at the [police] headquarters they thought that it would be they, the Slovaks, who would have to leave if if the revolution is successful. Anyicska was Lacušan's daughter, ... and a report even found its way to Comrade Novotný's desk, that the Hungarians in Slovakia sympathize with the revolutionaries, and that they are expecting the American troops.

... hogy jó kis botrány lett belöle, mert a parancsnokságon azt gonndolták hogy nekik, szlovákoknak kell majd kitakarodniuk, ha gyöz a forradalom. Anyicska Lacušannak volt a lánya, ... még Novotný elvtárs asztalára is felkerült egy jelentés arról, hogy a szlovákiai magyarok szimpatizálnak a felkelökkel, és várják az amerikai csapatokat. (135-136)

The absurdities of East Central European history become part of the story, even if seen through the distorted and maybe confused perspective of a five-year old and a bevy of gossips. Nothing is private, and fear permeates society. As Andrea Csilla Zólya points out:

Parallel to the biographical stories, the twentieth century history of the city of Iplolyság is sketched. But not only this, for the whole of life- and family histories, and the revival of the post World War I and II stories typically merges with the absurdity of East Central European history, and through these we get a glimpse into the background of the dramatic transformations of twentieth century history.

Élettörténeteikkel párhuzamosan körvonalozódik Ipolység városának huszadik századi történelme. De nemcsak ez, hiszen az egyes élet-és caládtörténetek, és a felvidéki magyarság elsö és második világhéborút követö történések felelevenitése tipikusan beleolvad a középkeleteurípai történelem abszurditásaiba, mint ahogy álataluk a huszadik századi történelem drámai alakulásinak hátterébe is betekintést nyertünk. (1)

Hunčik's work is informed by his own background: many of the characters and events are based on his own family history. The novel is also an amalgam of the life of his native town. The story, he noted, emerged while he was teaching in Ontario. Hunčik had held conflict resolution training and workshops in diffusing ethnic conflicts in Israel, Ireland, Azerbaijan and was invited to lecture at Carleton University in Ottawa. As an active figure in the post-Communist changes in Eastern Europe, he realized that the way to solve minority or ethnic issues was through a free and democratic society and the exchange of ideas. The novel grows out of such thinking. As Hunčik noted in a 2002 interview with Gábor Csanda, he began putting to paper the phantoms that emerged in his solitude: the grandparents, then the whole panoply of the Ipolyság (Csanda I. 2). By day, he was teaching political psychology of the $20^{\text {th }}$ century so the two themes merged naturally. Asked to be personal rather than academic in his lectures, he highlighted '56, '68, '38, the Vienna Awards and personal histories of the citizens of Ipolyság. (I.3) The history of the town seemed more and more to echo the history of Upper Hungary. With this background, it is not surprising that Határeset differs from the two earlier works in context and focus. Told from the perspective of Hungarians in a minority situation, it touches on earlier times when the Hungarians were the majority population, as well as the problematic years between 1938 and 1945. It is not the see-saw of minority and majority, however, that informs the work so much as the human relationships within the often irrational rules of the powers that dominate at any given time.

The past is never absent. As Zoltán Németh points out: "the uninterruptible, ceaseless stream of people, lives, events fills it; from this there is no escape, for surely these people are ourselves, its heroes and 
Basa,Enikő Molnár. "Multicultural Societies: Kálmán Mikszáth, Pál Závada and Péter Huncik." AHEA: E-journal of the American Hungarian Educators Association, Volume 5 (2012): http://ahea.net/e-journal/volume-5-2012

antiheroes are our ancestors and forbears, these events happened to them and to us” [emberek, életek, események megszakithathatlan, szakadatlan áramlása tölti be, amelyböl nincs menekvés, mert hiszen ezek az emberek mi vagyunk, a mi öseink és felmenöink a hösei és antihösei, ezek az események velük és velünk történtekk meg] (1). Hunčik does more than present the past; he approaches his subject form various angles until a complex society emerges which reflects the society of the interwar period in Slovakia as well as the years following the Second World War. The story goes up to approximately the Prague Spring in 1968. Nationality issues are complicated by the imposition of Communism because the party cadres always fear that many Hungarians are less committed to Communism than they should be. Thus there is prejudice against Hungarians as illustrated when Tomi Nemčak is being considered for disciplinary action. First, the judges consider linguistic issues: “After all, we are Communists according to our minds and hearts. Isn't that right? But according to our tongue we are Hungarians. And so it is with these two, together, comrades that we are such Communists” [Mert, mi, elvtársasak, ugyebár a szivünk és eszünk miatt vagyunk kommunisták. De a nyelvünk miatt vagyunk magyarok. És így együtt, elvtársak, mi olyan kommunisták vagyunk] (210). The mayor seeks to explain that they are Hungarians because of language, but no less good cadres for that. This does not convince the Communists from outside the region. Therefore, the debate between Communist loyalty and ethnic identity continues to form a thread in the work. In this instance, young Nemčak is let off easily: he will only need to go to a school in an area that is more thoroughly Slovak.

The question of which school a child should attend emerges as one of the recurring points of disagreement within the family, because choice caries meaning beyond the mere academic choice. Tomi comments:

Now he [granddad Nemčak] advised Dad that he should enroll me in a school there [i.e.Alsókubin]. Macocha patted my head, and said that after my eighteenth birthday I could re-write my name, and then I would become Nembuchovič like my ancestors. Dad did not even want to hear of this because he always considered himself to be Hungarian, and when I was enrolled in the first grade he already had had enough of an argument with Mother. Because, according to Mother, after kindergarten I would in any case remain Hungarian and so it would be logical, that I go to a Slovak school in the elementary grades. She contended that no one knows how long the Hungarian schools will function, and it would be easier for me also if I were to learn Slovak right away. And, furthermore, it would be better for Dad also, Mom continued, since if I attended the Slovak school he, too, would finally be let home from Beszterce and the family would be together.

Most meg azt tanácsolta apunak, hogy írasson be egy ottani iskolába. Macocha megsimogatta a fejememet, és azt mondta, a tizenyolcadik szülesésnapom után a nevemet is átirhatom, és akkor újra Nembuchovičnak hívhatnak, mint az öseimet. Apu hallani sem akart erröl, mert ö mindig magyarnak tartotta magát, és amikor volt a beiratkozá az elsőbe, ö már eleget vitatkozott erröl anyuval. Merthogy anyu szerint az óvoda után én már úgyis megmaradok magyarnak, ezért az volna a logikus, hogy szlovák elemibe járjak. Azt magyarázta, hogy úgysem tudja senki, meddig fognak müködni a magyar iskolák, és nekem is könnyebb lesz az életben, ha rögtön az elején megtanulok szovákul. Meg aztán apunak is jobb lenne, folytatta anyu, mert ha én szlovák iskolába járnék, akkor öt végre hazaengednék Besztercéröl, és együtt lenne a család. (217-218)

The novel's style is stream of consciousness with elements of magical realism. Since the narrators are mostly children both the matter-of-fact narration of often puzzling events, and the occasional flights of fantasy fit without disturbing the basic reality of the story. There is no real plot, yet the novel can be read, as 
Basa,Enikő Molnár. "Multicultural Societies: Kálmán Mikszáth, Pál Závada and Péter Huncik." AHEA: E-journal of the American Hungarian Educators Association, Volume 5 (2012): http://ahea.net/e-journal/volume-5-2012

Zsolt Németh points out, as a historical novel since it recounts the human history of the $20^{\text {th }}$ century, sometimes from a narrow, local perspective, sometimes from the distance of political power plays. We can also consider it to be a family novel since the fate of several generations forms the bulk of the narrative. It may even be viewed as a Bildungsroman since naive children's views gradually become the bearers of a complex consciousness. Most importantly:

... Határest is a novel of fate which recounts the tribulations of an ethnic group, the Hungarians of Slovakia, in such a way that it constantly forces this group into interaction with other viewpoints; thus it becomes a complex, many-layered expression of knowledge and experience.

Self-refection and self criticism become possible through this technique.

... Határeset olyan sorsregény is, amely úgy meséli el egy népcsoport, a szlovákiai magyar sorsközösség megpróbáltatásait, hogy közben minduntalan más nézöpontokkal kényszeríti interakcióba, ezzel válik összetett, sokrétü tudás és tapasztalat hordozójává, s ezzel a technikával lesz lehetséges az önreflexió és önkritika.' (1)

I believe this assessment comes closest to the definition of the novel: past, present and future interweave and each informs the other. The childish perspective provides a certain distance from facts. In this way, he harshness of many events are toned down.

An example of this method is the tale told of the experiences of the local soldiers in Wordl War II. Tomi, one of the principal narrators, recalls the story as told by Béla bácsi, a relative who comes to visit occasionally and regales the family with tales. One such tale recounts how the soldiers from Upper Hungary were considered unreliable during the Second World War by the Hungarian military. As a result of the First Vienna Award, the area had again become part of Hungary but units from these territories were not trusted and were considered expandable. Béla comments that they were all sent to the front, while the "ludovikások" ${ }^{4}$ remained at home: "They said that we were red Masaryk dogs, and straightway took us all the way to Voronyezh. When the Russian offensive came in January, the Ludovika officers all got on airplanes and fled. If it were not for Miklós, I, too, would have perished” [Azt mondták ránk, hogy vörös Masaryk-kutyánk vagyunk, es már vittek is egészen Voronyezsig. Mikor januárban jött az orosz áttörás, a ludovikás tisztek mind repülögépre ültek és menekültek. Ha nem lett volna Miklós, én is odaveszek, mondta Béla bácsi] (198). Taking command, the chaplain Miklós, who is another relative and who leads a most adventurous life, gets the unit into marching order and with iron discipline and no-nonsense attitude, leads most of them home:

According to uncle Béla, at the end of January almost three hundred privates set out for home from the Don under Uncle Miklós’ leadership, and by the end of April all arrived at the range of the Carpathians with only twenty some persons missing. The partizans did not dare attack such a large group, and the Germans saluted when we filed past. Miklós kept order. I want to see the end of the row, he roared, and the privates immediately ordered the lines.

Béla bácsi szerint január végén majdnem háromszáz baka indult haza a Dontól Miklós bácsi vezetésével, és április végére húszvalahány ember híjján mind megérkeztek a Kárpátok vonalához. A partizánok ilyen nagy csapatot nem mertek megtámadni, és németek is szalutáltak amikor elvonultunk elötük. Miklós rended tartott. Látni akarom a sor végét, üvöltözte, és a bakák azonnal rendezték a sorokat. (197-198)

Such accounts form part of the magical realism of the novel: characters whose actions change - or attempt to 
change - history. (Németh 1-2)

Tolerance, or the lack of it, is the underlying message. Tolerance characterizes the dealings of the townspeople among themselves, regardless of ethnic or political affiliation. As Communism is consolidated after the war, the mayor declares that they are Hungarian in language but Communist in sentiment, as quoted above in connection with the disciplinary action against Tomi. Of course, this little gem of tolerance is buried within pages of fulsome praise of Stalin, the Soviet Union, Czechoslovak Communism, and so on, so that there is an ironic note as well. The irony is heightened by the recommendation that Tomi be sent to school in a more solidly Slovak area, presumably to transform him into a "true" Slovak. Outside forces work against the tolerant attitudes of the locals. We know, and are reminded again in the family council's discussions, that Tomi's father, in spite of holding a law degree, has been exiled as a laborer to the remote town of Beszterce (Banská Bystrica) because of his Hungarian sentiments. Discrimination against the Hungarian population in Czechoslovakia, particularly after World War II, affected the intelligentsia and businessmen most heavily. Even if they were not deported, they often ended up in internal exile, stripped of citizenship and considered war criminals according to the Beneš decrees. Both Tomi's grandfather, who ran a patisserie shop, and Laci Löwenthal, the Jewish pharmacist, lose their shops and can only work as assistants to their former employees.

The tribulations of the Hungarian population, of course, become worse as the Communists consolidate their power and ethnic tensions escalate, often driven by outside forces. Mr. Löwenthal is detained in January of 1957 because he "joked" about deportations:

The gendarmes appeared the next day and took him away because he joked in Hungarian, albeit at that time even we children were not allowed to speak loudly in the city. This was understood even by István and Pipityu, even though they had not been banned from kindergarten, only their fathers had been taken away as "volunteers" and uncle Feri and uncle Hemrik could not even come home for Christmas eve.

A csendörök már másnap jelentkeztek, és elvitték öt, mert magyarul viccelödött, pedik akkor még nekünk gyerekeknek sem volt szabad hangosan beszélnünk a városban. Ezt még István és Pipityu is megértette, pedig öket nem tiltották ki az óvodából, csak az apukájukat vitték el önkéntesnek, és Feri bácsi meg Hemrik bácsi még szentestére sem jöhetett haza. (222)

The question of identity permeates the work and different reactions are presented. Almost no one is without a mixed heritage. Before Tomi and Pali's father declares himself to be French, a family council is held on how the Beneš decrees will affect them. Grandfather Nemčak urges his son to sign the papers in which he claims to be Slovak:

The decrees of President Beneš were not drafted by your Cicero, but by Cato. For, from the whole or Roman law only one sentence has been retained, namely vae victis...

If tomorrow you sign the papers, then the state will acknowledge your Hungarian diploma and within a few weeks you can be a lawyer. This is what you always dreamed of, no? ...In this country there will no longer be Géza. nor Antal, nor András, only Onrdej and Anton and Gejza. Don’t you understand?

Beneš elnök dekrétumait nem a te Ciceród állitotta össze, hanem Cato. Mert az egész római jogból csak azt az egy mondatot hagyták meg, hogy vae vicits...

Ha holnap aláírod a papírokat, akkor az állam elismeri a magyar diplomádat, 
Basa,Enikő Molnár. "Multicultural Societies: Kálmán Mikszáth, Pál Závada and Péter Huncik." AHEA: E-journal of the American Hungarian Educators Association, Volume 5 (2012): http://ahea.net/e-journal/volume-5-2012

és pár héten belül advokát lehetsz. Mindig erröl álmodoztál, vagy nem?...

Ebben az országban nem lesz többé se Géza, se Antal, se András. Csak Ondrej meg Anton meg Gejza. Hát nem érted?” (285; 286)

Each border change seems to carry threats of deportation. In 1945 the Nemčak family council comments that if everyone with a Hungarian connection were deported, only three families would remain in the city. The complexity and injustice of these political decisions is made clear in the dialogue between the father and the grandfather. The elder man had also been forced to leave his family in 1939, being regarded as not native. He had settled in Ipolyság when he married into a local family, hailing from the more thoroughly ethnically Slovak Alsókubin region. Yet he was devastated at having to leave the family, which was considered Hungarian - as he considered himself as well. But he could not deny his roots, either:

Of course, I would only have had to sign that I was really Hungarian.

Just as now you only have to acknowledge that you are really Slovak and the environment Magyarized you.

Dad did not agree with this at the time, but later he recounted to us that Grandfather Nemčak was still right to some extent, for if there are not the seven years between thirty-nine and forty-five, when we again became Hungarians, there would be no Hungarians living in Slovakia today.

Persze, csak azt kellett volna aláírnom, hogy tulajdonképpen magyar vagyok. Mint ahogy neked is csak azt kell most beismerned, hogy tulajdonképpen szlovák vagy, csak a környezetet elmagyarosított.

Apu akkor nem értett ezzel egyet, de később azt mesélte nekünk, hogy Nemčak nagyapának mégiscsak igaza volt valamiben, mert ha nincs az a hét év harminckilenc és negyvenöt között, amikor megint magyarok lettünk, akkor ma már nem élne magyar Szlovákiában. (271)

The naive viewpoint of the child emphasizes the multilingual, multiethnic nature of the region. For example, the realization that in Alsókubin almost no one speaks Hungarian confirms that the Slovak presence is ancient and undoubted in parts of Upper Hungary, now Slovakia. But in the Csallóköz (the region of the Danube delta as the river breaks through the Alps to spread out on the Hungarian plain before again being confined within more defined borders) only Czech and Slovak "colonists" settled there after 1920 do not speak Hungarian. (269) The children accept the explanation, just as they accept other changes in the school, but the reader is expected to recognize the bias. The speaker is a teacher, Mr. Herányi, who attempts to instill Hungarian nationalism into his charges.

Határeset continues to explore ethnic tensions into the 1960's. The Prague Spring confronts the Hungarian population with the ironic and tragic fact of Hungarian support of the Soviet invasion, in accordance with the Warsaw Pact. While there is certainly no denial that individuals are often intolerant, time and again it is shown that outside forces exacerbate the situation. Pipityu, the son of the local shepherd and Slovak in ethnicity, relates the town's reactions to events in Hungary in 1956:

In October of Fifty-six the police were extremely nervous. The patrolled the streets night and day, and along the river they built guard posts for they knew that everyone had relatives on the other side. First they took Sóbujtó for interrogation, then the reverend father, after that Uncle Feri and all those who were in the Hungarian army during the war.

Ötvenhat októberében a csendörök nagyon idegesek voltak. Éjjel-nappal járöröztek az utcákon, még a folyó mentén is állasokat építettek, mert tudták, hogy mindenkinek van rokona a másik oldalon. Elöször Sóbujtót vittél el kihalgattásra, aztan a tisztelendö urat, utánuk Feri bácsit meg azokat, akik 
Basa,Enikő Molnár. "Multicultural Societies: Kálmán Mikszáth, Pál Závada and Péter Huncik." AHEA: E-journal of the American Hungarian Educators Association, Volume 5 (2012): http://ahea.net/e-journal/volume-5-2012

a háborúban a magyar hadseregben harcoltak. (70)

Pipityu is a neutral observer; he is not part of the family, only a friend and schoolmate of the chief protagonists. He is the first narrator and so helps set the tone of the work. I believe that the fact that an "outsider" introduces the work is significant. Through this narrative passage the community of the city, presumably Iploylság but certainly standing in for many of the multiethnic communities of Southern Slovakia, is shown as open to many nationalities. Hungarians, Slovaks, Jews and Gypsies co-exist here in spite of the efforts by successive governments to force it to become a monocultural area. The threads tying them together reach back to a time when ethnic identity was not a separating issue. One was simply what he was just as his name was what it was, or his job, or maybe even whether he was fair-haired or dark: a matter of fact without political content. In many ways this reflects the attitude in Mikszáth and Závada who also show an impatience with compartmentalization.

Hunčik's professional work involves conflict resolution, and having lived the multiethnic experience he can sympathize with the choices which had to be made by many. He is also keenly aware of the instances where no choice is possible, where people are simply deported, or worse, on the basis of their nationality or race. Even Géza's declaring himself French does not solve the problem of being ethnically Hungarian in post World War II Czechoslovakia or post 1993 Slovakia. In the interview with Gábor Csanda, Hunčik states:

For it is very rare that there is only one truth, and it is also dangerous. The twentieth century became dangerous from the truths that were seen as unique, when only one theory, one philosophy was given validity, and every one had to orient themselves to this; it is from this that their personalities were destroyed; their lives, their all was destroyed in this.

Mert nagyon ritka az, amikor csak egy igazság van, és nagyon veszélyes is. A huszadik század is ezektől az egynek hitt igazgágoktól vált veszélyessé, amikor csak egy elmélet, csak egy filozófia érvényesült, s mindnekinek ehhez kellett igazodnia, és ettöl ment tönkre a személyiségük, az életük, a mindenük ebben ment tönkre. (III.2)

Many lives were ruined and talents squandered. When Géza bácsi, the lawyer, is finally allowed to return home, he is told that everything will return to normal. The local comrades, in spite of knowing that he is a lawyer, assign him to teach aesthetics at the local agricultural school. In spite of his ignorance of animal technology, he is told to teach what he can since this is a new opportunity:

You will teach what you know, he said. The point is, that there be no hitch in the academic course. And from the following month the young zoology technicians were learning Latin and in their spare time were translating Vergil. And when colleague Bulkovszky was run over by a bus and became crippled, Uncle Géza also took over the teaching of the Slovak language.

Azt fogsz tanítani, amihez értesz, mondta. A lényeg az, hogy ne legyen fennakadás a taitás menetében. És a következö hónaptól a fiatal zootechnikusok már a latin nyelvtant tanulták, és szabad idejükben Vergiliust fordították. Amikor aztán Bulkovszky kollégát elütötte az autóbusz és megsántult, Géza bácsi a szlovák nyelv tanítását is átvehette. (350)

He taught what he knew, and the students did well, one of them even becoming Assistant Minister for Agriculture (351). The whole incident illustrates the travesty of a system in which a person teaching is classics instead of the practical courses required of the school, while at the same time his training in law is 
Basa,Enikő Molnár. "Multicultural Societies: Kálmán Mikszáth, Pál Závada and Péter Huncik." AHEA: E-journal of the American Hungarian Educators Association, Volume 5 (2012): http://ahea.net/e-journal/volume-5-2012

not recognized simply because refused to deny his Hungarian background. Even when he eventually gets a position where his legal training is recognized, the position is below what it should be:

Twenty years after the completion of the university he was finally able to do the work which was his field. He became a lawyer, more precisely, he was able to work in the municipal grain purchasing unit, and he could write the contracts on how many tons of wheat and barley the plant buys from the surrounding collectives. The grain was stored in an old building, right next to Granddad's house. Aunt Klari could still remember when, before the war, the Jews went to pray there. But then it was not called a granary, instead it was called a synagogue.

Húsz évvel az egyetem elvégzése után végre azt a munkát csínálhatta, amihez értett. Jogász lett, pontosabban a városi gabonafelvásárló üzemben dolgozhatott, és írhatta a szerzödéseket arról, hogy hány tonna búzát meg árpát vásárol fel az üzem a környezö szövetkezetektöl. A gabonát egy régi épületben tárolták, közvetlenül nagyapuskáék háza mellett. Klári néni még emlékezett arra, hogy a háború elött a zsidók jártak ide imádkozni. De akkor még nem úgy hívták, hogy magtár, hanem úgy, hogy zsinagóga. (352)

This brief comment illustrated two things: even in the 1960's, Hungarians in Czechoslovakia were not allowed full opportunities since the task assigned to Géza are those any law student or legal intern could do. Moreover, what seems to be an aside about the former synagogue illustrates the lack of respect for Jewish sites under Communism with synagogues turned into granaries and similarly unsuitable used.

The most telling incident about the complex history of the region is given in Feri's final account. The group, now at university in Pozsony (Bratislava) try to understand the pro Tiso and anti Hušak factions. It is a period of relative freedom, so one of the students, Klečko reveals that his father, who was a landowner, was in a labor camp as punishment for having land. Laci Muránsky reveals that his father had been an officer at the same camp, sent there because he had failed to join the Communist party even though he had led a partisan unit against the Fascist government (375). As the young Feri realizes, Yalta and Teheran not only committed an injustice on Hungarians but on all of the peoples of the region - though in the family it was accepted fact that the Hungarians always drew the shortest straw (376). With the realization of the duplicity of politics, Feri finds that Dubček's assurances of a more just state ring hollow. When he confronts Dubček, pointing out that the role of Husák has to be questioned because, while he might be a hero in Prague, he was the person largely responsible for the deportations in the Hungarian regions, Dubček replies: "You know, Ferko, during the building of Communism we committed many errors, but if we now consolidate our lines, and speak openly about everything, in a few years there will be no hatred in our country, and you, Hungarians, will live as if you were at home” [Tudja, Ferko, a kommunizmus építése során sok hibát követtünk el, de ha most összezárjuk a soranikat, és mindenröl öszintén fogunk beszélni, néhány év mulva nem lesz az országban gyülölködés, és maguk, magyarok is úgy fognak élni, mintha otthon volnának] (378).

Aside from the ironic implications that Hungarians are not at home in the Czechoslovak state, in spite of having a thousand-year plus physical presence in the area, the condescending tone points to feeling of superiority the Czechs exhibit. The Prague Spring elicits mixed feelings: the loosening of dictatorial restrictions is certainly welcome, but the anti-Hungarian sentiment is worrisome (385). Furthermore, Warsaw Pact troops called in to put down the liberalizing movements in Czechoslovakia included Hungarians who even kill one of the students (391). There is no escape from the manipulation of the populace. The final indignity is delivered when there is an attempt to recruit Géza bácsi into the Secret Police. The authorities hold out a combination of threats and bribes as they hope to force Géza to inform on his friends and even family. The conclusion is left in the air, but one suspects that he does give in to various pressures though opposed to the very idea (442-448). As the post 1989 revelations from the archives of the various secret police reveal, the spy network of the Communist states was so pervasive that hardly anyone 
Basa,Enikő Molnár. "Multicultural Societies: Kálmán Mikszáth, Pál Závada and Péter Huncik." AHEA: E-journal of the American Hungarian Educators Association, Volume 5 (2012): http://ahea.net/e-journal/volume-5-2012

escaped, even though many of the informants supplied little useful information to the authorities.

The lives of the inhabitants of central Europe is the subject of the novel. In the twentieth century intolerance came to dominate public and sometimes even private actions. The earlier era of tolerance and easy acceptance of multiple ethnicities within a given region gave way to a desire to impose a monoethnic culture upon a multiethnic community. Intolerance led to forcible expulsions, relocations, denial of citizenship, and economic persecution. This was particularly true in the successor states where the nationalistic states sought to transform what were multiethnic communities in communities where only one ethnicity, that of the new majority, prevailed. As is illustrated in the work of Hunčik, the only way to eradicate the Hungarian presence in southern Slovakia was to deport the large segments of the population and to force others to deny their roots. As seen from the example of Mikszath, tolerance characterized Upper Hungary in the nineteenth century. In the twentieth century both sides showed intolerance to those not belonging to the majority population, whether Slovak or Hungarian. Such intolerance, concomitant with the rise of nationalism, led to conflicts. The key, Závada but particularly Hunčik suggest, is to accept individuals for who they are, rather than reject groups based on prejudiced stereotypes. For an example of this, we can reach back to Mikszáth and a more inclusive era. All three authors suggest that acceptance of the ethnicity and language of others leads to a richer community than the repression of those who differ in any way from the majority. Mikszáth wrote in a society that by and large accepted a multiethnic and multilingual community. Závada is still working in this framework, albeit at a time when ethnic/nationalistic issues begin to dominate politics. Hunčik's novel shows the breakdown of civility, the threats to identity, and the animosity that can be generated among closely related groups when political agendas support separateness rather than unity.

At the Szeged AHEA Conference in 2000 Hunčik posed questions on Hungarian-Hungarian relations. In the elections that year, the right of center FIDESZ was returned to power in Hungary; in Slovakia, the ultra-nationalist government of Mečiar was replaced by a more moderate government. Hunčik postulated that the elections might give two Hungarian parties seats in the Slovak Parliament: the "purely Hungarian” MKP and the Hid which reaches out to Slovak and other nationalities as well (Abstract). Hunčik, obviously, is open to a multi cultural approach. One can only hope that all of the countries in the region recognize their being interconnected not only by ethnicity and language, but also by a shared history and family ties which intertwine. The novels remind us that historical Hungary always had minority populations., and the successor stated have inherited a similarly mixed population. In the final analysis, all three authors, Mikszáth, Závada and Hunčik based their stories on their own experiences. This is not a bad thing: in a multicultural setting, recognition of the shared heritage of a region can only lead to more understanding. A novel, a work of fiction, can serve as the means to understanding. A novel, a work of fiction, can serve as a means to understanding, as s Hunčik points out: a motivatin for writing Határeset was his need to create "a memoir of Ipolyság” (Csanda IV 2-3).

There is hope that within the European Union the wider view of interpersonal and interethnic relations will gain ground. This is the path traced by Szilvia Szoták in a paper where she argues: "The changes which have occurred in East-Central Europe within the expansion of the European Union have led to ever greater emphasis on minority languages in the countries neighboring Hungary. The majority language, multiculturalism, bi (multi) lingual education have become key issues in the policy of most European countries. Bilingualism has identified advantages in both the economic and sociological sphere" (Abstract.) The presentation reinforces the message of the novels: multiethnic, multi linguistic, multi cultural societies are richer than those which restrict their populations. Politics is often short-sighted in focusing on the nineteenth century concept of the national state rather than the multi cultural community which makes up most modern states. It might take some time for the nationalistic mind-set to be divorced from the idea of the nation state. The multi linguistic and multiethnic realities of the world we live in will also take some time for acceptance. This should not, however, deter us from viewing a common language, culture, and literature, as well as a shared history, as a unifying factor across national boundaries. Nor should it prevent us from embracing the openness of Mikszáth, Závada, and Hunčik in dealing with Hungarian neighbors in the Carpathian basin. 
1. A shorter version of this paper was delivered at the $36^{\text {th }}$ Annual Conference of the AHEA in Cleveland, Ohio, 14-17 April, 2011.

2. The decrees declared the "collective guilt" of ethnic Germans and Hungarians in postwar Czechoslovakia and led to the deportation of three million Germans and Hungarians from the lands that had been their homes for centuries. The laws were in blatant violation of human rights and are also contrary to concepts of international law, sanctions against discrimination and forced labor and the right of private property, since of those who were not banished were stripped of citizenship and subject to arbitrary seizure of property and forced labor service. Both the Czech and the Slovak Republics consider these decrees part of their legal system even now. Even though they are blatantly at odds with the Basic Rights guaranteed by the European Union, the Slovak Parliament confirmed their validity in 2007.

3. All translations from Hungarian texts, both the works under discussion and the critical material, are mine.

4. Hungarian officers who were graduates of the Ludovika Military Academy.

\section{Works Cited}

Alexa, Károly, “Magyar táj tót ecsettel.” [Hungarian Scene with a Slovak Brush] Kortárs 42.3 (1998): 105111.

Angyalosi, Gergely, et al. "Závada Pál Jadviga párnája című könyvéről beszélget Anygalosi Gergely, Bán Zoltán András, Németh Gábor és Radnóti Sándor.” [Gergely Anygalosi, Zoltán András Bán, Gábor Németh and Sándor Radnóti Converse on Pál Závada’s Book Entitled Jadviga’s pillow] Beszélő II.8 (1997) http://beszelo.c3.hu/cikkek/

Csanda, Gábor. “Határeset. Csanda Gábor beszélgetése Hunčik Péterrel - I. rész-IV.rész.” [Border Incident. Gábor Csanda’s Conversation with Péter Hunčik Parts I-IV] Új Szó Szalon. Dec. 20, 2008

Supplement. http://ujszo.com/online/kultura/2008/12/21/

Hunčik, Péter. Határeset. [Border Incident] Pozsony: Kalligram, 2009.

."Magyar-szlovák kapcsolatok lehetőségei az idei választások vetületében." [The Possibilities of Hungarian-Slovak Connections in Projection of the Current Elections] AHEA Conference. Szeged, Hungary. 3-5 June, 2000. Abstract at http://ahea.net/conferences/2010/submitted-papers?

Legeza, Ilona. “Könyvismertetője: Závada Pál Jadviga párnája.” [Her Book Review: Pál Závada’s Jadviga párnája] http://legeza.oszk.hu/sendpage.hp?rec=li2425

Mikszáth, Kálmán. Tót atyafiak. A jó palócok. [Slovak Relations. The Good Palóc] Budapest: Móra Könyvkiadó, 1978.

A Magyar irodalom története 1849-töl 1905-ig. [The History of Hungarian Literature from 1848 to 1905]

Ed. István Sőtér. A Magyar irodalom története. Budapest: Akadémiai Kiadó, 1965.

Nemsekürty, István. Diak, irj magyar éneket. [Scribe, Write a Hungarian Song] Budapest: Gondolat, 1985.

Németh Zoltán. “Történelrm a határon - Hunčik Péter határEset címü regényéről," [History on the Border About Péter Hunčik’s novel entitled borderIncident] Irodalmi Szemle (2009 junius 9): 17:33. http://jogazda.sk/kiado/index.php?option=com_content\&view

Petra, Mihüly. “Egy ‘izig-vérig normális regény.”' [A 'Thorougly Normal Novel’] Iskolakurtúra. (2005.5): 79-88.

Rakovszky, Zsuzsa. “A vadasmártás íze.” [The Taste of the Sauerbraten Sauce] Beszélő 3.5 (1998): 116-

122. http://beszelo.c3.hu/cikkek/ 
Sándor, Zsuzsanna. “A Hunčik regény: Egy demokrata magánrendelöje.” [The Hunčik Novel: the Private Consulting Room of a Democrat] 168 Óra Online. 2009 December 19: 08-29 http://www.168ora.hu/globusz/

“Slota megoldja a kissebbségi problémát: a magyarok és a cigányok keljenek át a Dunán’ [Slota Solves the Minority Problem: Hungarians and Gypsies Should Cross the Danube] Népujság 67 (Wed. 23 March, 2011). Cited in Hungarian Human Rights Foundation Newsletter http://www.hhrf.org/nepujsag/10mar/10nu0325t.htm

Szoták, Szilvia. "Kétnyhelvüség Burgenland iskoláiban.” [Bilingualism in the Schools of Burgenland] AHEA Conference, Szeged, Hungary. 2-5 June, 2000. Abstract at: http://ahea.net/conferences/2010/submitted-papers?

Szalay, Zoltán. "Pluralista stilisztika egy ipolysági anekdótaregényben.” [Pluralitstic Stylistics in an Anecdotal Novel of Iplolyság] Irodalmi szemle 52.4 (April 2009). http://www.litera.hu/hirek/rendszervaltozasok-a-magyar-irodalomban

Szerb, Antal. Magyar irodalomtörténet. [Hungarian Literary History] Budapest: Magvető Könyvkiadó, 1959.

Wlachovszký, Karol. “Palócország és a palócok Mikszáth képzeletében és a valóságban.” [Palóc Country and the Palóc in Mikszáth’s Immagination and in Reality] Irodalmi Szemle. 53.4 (May 2011) http://www.irodalmiszemle.sk/

Závada, Pál. Jadviga párnája.; napló. [Jadviga’s Pillow: Diary] Budapest: Magvető, 1997. -. “Beszélgetés Závada Pállal: ...’Csoda az ezredvégén...’ [A Conversation with Pál Závada: ...’Miracle at the Turn of the Millenium...'] (Interview on Radio Vörösmarty, Spring 1999. http://www.kodolanyi.hu/szabadpart/szam4/irod/deli.htm

Zólya, Andrea Csilla. "Ha a rézangyalok mesének...” [If the brazen angyels tell a tale...] Uj szó Online. (Fri. Dec. 19, 2008) 19:58. http://ujszo.com/online/kultura/2008/12/19/ 